\title{
UPAYA MENINGKATKAN HASIL BELAJAR EKONOMI MELALUI MODEL PEMBELAJARAN KOOPERATIF TIPE JIGSAW PADA PESERTA DIDIK KELAS XI-8 SMAN-4 PALANGKA RAYA
}

\author{
Oleh \\ Juliansyah,* Ilham** \\ Ilham@yahoo.com
}

\begin{abstract}
This study aims to improve learning outcomes and describe the learning activities of students in the process of economic learning using the Cooperative Type Jigsaw learning model. The subjects in this study amounted to 37 students of class XI-8 of SMAN-4 Palangkaraya. The method used is to use Classroom Action Research (CAR). For data collection techniques used are observation, documentation, and tests. research results: (1) Learning activities of students are more active during the economic learning process by using the Cooperative Type Jigsaw learning model; (2) There is an increase in economic learning outcomes. This is seen from the data on student learning outcomes, in the first cycle the average student learning outcomes were 70.14 and classical completeness was $64.86 \%$ and in the second cycle it increased to 83.24 and classical completeness was $86.49 \%$. The minimum standard for completeness determined by schools for Economics is 75 .
\end{abstract}

(C) Muhammadiyah Palangkarya of University

Keywords: Learning Outcomes, Type Jigsaw Cooperative Model

\begin{abstract}
ABSTRAK
Penelitian ini bertujuan Untuk meningkatan hasil belajar dan mendeskripsikan aktivitas belajar peserta didik saat proses pembelajaran Ekonomi dengan menggunakan model pembelajaran Kooperatif Tipe Jigsaw. Subjek dalam penelitian ini berjumlah 37 orang peserta didik kelas XI-8 SMAN-4 Palangkaraya. Metode yang digunakan adalah menggunakan Penelitian Tindakan Kelas (PTK). Untuk teknik pengumpulan data yang digunakan adalah observasi, dokumentasi, dan tes. hasil penelitian: (1) Aktifitas belajar peserta didik lebih aktif pada saat proses pembelajaran Ekonomi dengan menggunakan model pembelajaran Kooperatif Tipe Jigsaw; (2) Ada peningkatan hasil belajar Ekonomi. Hal ini telihat dari data hasil belajar peserta didik, pada siklus I rata-rata hasil belajar peserta didik yaitu 70,14 dan ketuntasan secara klasikalnya yaitu 64,86\% dan pada siklus II meningkat menjadi 83,24 dan ketuntasan klasikalnya yaitu 86,49\%. Adapun standar ketuntasan minimum yang ditentukan sekolah untuk pelajaran Ekonomi yaitu 75 .
\end{abstract}

CUniversitas Muhammadiyah Palangkarya

Kata Kunci: Hasil Belajar, Model Kooperatif Tipe Jigsaw

Juliansyah* Mahasiswa FKIP UM Palangkaaraya

Ilham** Dosen Universitas Muhammadiyah Palangkaraya 


\section{PENDAHULUAN}

Pendidikan merupakan upaya yang strategis dalam meningkatkan sumber daya manusia dan upaya mewujudkan cita-cita bangsa Indonesia dalam mewujudkan kesejahteraan umum dan mencerdaskan kehidupan bangsa. Negara Indonesia sebagai Negara yang berkembang dalam pembangunan membutuhkan sumber daya manusia berkualitas yang dapat diandalkan. Salah satu usaha menciptakan sumber daya manusia berkualitas yang dapat diandalkan adalah melalui pendidikan. Pendidikan adalah usaha sadar untuk menumbuhkan dan mengembangkan potensi sumber daya manusia. Hal ini sesuai dengan tujuan pendidikan nasional sebagaimana tercantum dalam Undang-Undang Republik Indonesia No. 20 Tahun 2003 tentang Sistem Pendidikan Nasional adalah sebagai berikut: Pendidikan nasional berfungsi mengembangkan kemampuan dan membentuk watak serta peradaban bangsa yang bermartabat dalam rangka mencerdaskan kehidupan bangsa, bertujuan untuk berkembanganya potensi peserta didik agar menjadi manusia beriman dan bertaqwa kepada Tuhan Yang Maha Esa, berakhlak mulia, sehat. berilmu, cakap kreatif, mandiri dan menjadi warga negara yang demokratis serta tanggung jawab.

Salah satu indikasi pencapaian proses pendidikan tersebut adalah terwujudnya hasil belajar peserta didik yang memuaskan. Belajar adalah suatu proses usaha yang dilakukan seseorang untuk memperoleh perubahan tingkah laku yang baru secara keseluruhan, sebagai hasil pengalamannya sendiri dalam interaksi dengan lingkungannya ( Slameto,2003:2). Pendidikan dapat dikatakan berhasil apabila tercapai hasil belajar yang baik atau peserta didik mendapatkan nilai di atas ratarata. Namun, peserta didik akan menemui hal-hal yang akan mendukung maupun menghambat mereka dalam mencapai prestasi belajar yang memuaskan.

Dalam kegiatan pembelajaran peran guru juga menentukan dan mensukseskan program pendidikan, serta menunjang tercapainya keberhasilan belajar peserta didik untuk terciptanya pembelajaran yang efektif dan efisien. Adapun kegiatan pembelajaran yang efektif dan efisien akan tercapai dan tercipta apabila guru mampu memilih dan mau mengembangkan serta menggunakan model-model pembelajaran yang tepat untuk menyampaikan materi pembelajaran kepada peserta didik, apabila kurangnya partisipasi dan keaktifan peserta didik dalam kegiatan pembelajaran akan membuat peserta didik merasa jenuh, sehingga menimbulkan keributan dalam kelas yang berdampak pada hasil belajar peserta didik. Oleh sebab itu peserta didik diharapkan dapat berpartisipasi dan berperan aktif dalam kegiatan pembelajaran untuk menghindari terjadinya keributan dalam kelas agar dalam kegiatan belajar mengajar dapat mencapai tujuan hasil belajar yang diinginkan. 
Usaha-usaha

dalam

membelajarkan peserta didik merupakan bagian yang sangat penting dalam pencapaian keberhasilan tujuan pembelajaran yang sudah direncanakan. Oleh karena itu pemilihan model pembelajaran merupakan suatu hal utama. Model pembelajaran adalah pedoman berupa program atau petunjuk strategi mengajar yang Berdasarkan hasil observasi yang dilakukan peneliti pada peserta didik kelas XI-8 SMAN 4 Palangkaraya, fenomena yang dapat dijumpai di sekolah menunjukkan bahwa pelaksanaan kegiatan pembelajaran masih ditemukan kurangnya partisipasi dan keaktifan peserta didik sehingga menimbulkan keributan dalam kelas ketika guru menyampaikan pembelajaran, kurangnya kreativitas atau keterampilan guru dalam mengembangkan pembelajaran serta guru masih banyak menggunakan metode ceramah, dan tidak pernah menggunakan model pembelajaran kooperatif tipe Jigsaw. Sehingga ini menyebabkan rendahnya perolehan hasil belajar Ekonomi peserta didik kelas XI-8 SMAN-4 Palangka Raya masih belum mencapai nilai standar. dirancang untuk mencapai suatu tujuan pembelajaran. Masih rendahnya hasil belajar Ekonomi disebabkan diantaranya oleh masih dominannya kemampuan menghafal dari pada kemampuan memproses sendiri pemahaman suatu materi. Selama ini, minat belajar peserta didik terhadap mata pelajaran Ekonomi masih tergolong sangat rendah. Hal ini dapat dilihat pada sikap peserta didik selama mengikuti proses pembelajaran tidak fokus, sibuk sendiri, sering bercanda, tidak berkonsentrasi mengikuti pelajaran, ngobrol dengan teman sebangku, menganggu teman sebelah dan belakangnya, dan sering memainkan handphone saat proses pembelajaran. Sehingga Guru juga kesulitan mengontrol peserta didik yang ribut dan keluar masuk ruangan pada saat proses pembelajaran. Bahkan ada sebagian peserta didik yang menganggap mata pelajaran Ekonomi tidak begitu penting. Sehingga tujuan pembelajaran menjadi tidak tercapai secara maksimal. Faktor itu juga dipengaruhi oleh adanya metode mengajar yang digunakan guru dalam menyampaikan materi.

Metode pengajaran belum bervariasi yaitu metode ceramah, mencatat dan penugasan sering dilakukan dalam setiap pertemuan pelajaran Ekonomi. Suasana pembelajaran belum aktif interaksi yang terjadi hanya satu arah dimana guru yang lebih dominan berbicara, peserta didik lebih banyak diam, mendengarkan, ketika disuruh mencatat peserta didik mencatat dan diberikan tugas. Sehingga didalam proses pembelajaran peserta didik kurang aktif dan cenderung pasif dapat dilihat dari nilai rapot atau hasil belajar peserta didik. Kondisi pembelajaran seperti inilah yang mengakibatkan peserta didik kurang aktif dan pembelajaran yang dilakukan kurang efektif.

Untuk mengantisipasi masalah tersebut, maka perlu memilih strategi pembelajaran yang tepat. Para guru 
terus berusaha menyusun dan menerapkan berbagai strategi yang bervariasi agar peserta didik tertarik dan bersemangat dalam belajar Ekonomi. Salah satunya dengan menerapkan Model pembelajaran Kooperatif Tipe Jigsaw.

Menurut Wena (2010 : 193) mengungkapkan bahwa: Model Pembelajaran Kooperatif Type Jigsaw adalah suatu tipe pembelajaran yang terdiri dari beberapa anggota dalam satu kelompok yang bertanggungjawab atas penguasaan bagian materi belajar dan mampu mengajarkan materi tersebut kepada anggota kelompok yang lain.

Model pembelajaran Kooperatif tipe Jigsaw adalah salah satu dari model pembelajaran yang paling fleksibel, merupakan salah satu variasi model Collabirative Learning yaitu proses belajar kelompok dimana setiap anggota menyumbang informasi, pengalaman, ide, sikap, pendapat, kemampuan, dan keterampilan yang dimilikinya untuk secara bersama-sama saling meningkatkan pemahaman seluruh anggota.

Ada beberapa tahapan-tahapan penerapan Pembelajaran Model Jigsaw. Menurut Sanjaya,(2007:7) sebagai berikut:

a. Pilihlah materi belajar yang dapat dipisah menjadi bagianbagian. Sebuah bagian dapat disingkat seperti sebuah kalimat atau beberapa halaman.

b. Hitung jumlah bagian belajar dan jumlah peserta didik. Dengan satu cara yang pantas, bagikan tugas yang berbeda kepada kelompok peserta yang berbeda.

c. Setelah selasai, bentuk kelompok Jigsaw Learnig. Setiap kelompok ada seorang wakil dari masing-masing kelompok dalam kelas.

d. Kemudian bentuk kelompok peserta didik Jigsaw Learning dengan jumlah sama.

Selain tahapan ada pula beberapa kelebihan Model Pembelajaran Jigsaw seperti yang dikemukakan oleh beberapa ahli, sebagai berikut:

Menurut Nurhadi (2004:3): adalah sebagai berikut:

a. Meningkatkan kerja sama untuk mempelajari materi yang ditugaskan.

b. Meningkatkan rasa tanggung jawab peserta didik terhadap pembelajarannya sendiri danjuga pembelajaran orang lain.

c. Guru berperan sebagai pendamping, penolong dan mengarahkan peserta didik dalam mempelajari materi pada kelompok ahli yang bertugas menjelaskan materi kepada rekanrekannya.

d. Melatih peserta didik untuk lebih aktif dalam berbicara dan berpendapat.

e. Pemerataan penguasaan materi dapat dicapai dalam waktu yang lebih singkat.

Menurut Ibrahim, dkk (2003:120121)kelebihan dari belajar Jigsaw yaitu dapat mengembangkan perilaku dan hubungan yang lebih baik antar peserta 
didik antar peserta didik dan dapat mengembangkan kemampuan akademis peserta didik. Peserta didik belajar lebih banyak dan teman mereka dalam belajar dari pada dari Guru.

Alasan menggunakan model pembelajaran Kooperatif Tipe Jigsaw adalah untuk mengatasi masalah hasil belajar Ekonomi pada peserta didik kelas XI-8 SMAN 4 Palangkaraya. Model pembelajaran kooperatif Tipe Jigsaw merupakan salah satu tipe kooperatif yang menekankan pada adanya aktivitas dan interaksi diantara peserta didik untuk saling memotivasi dan saling membantu dalam menguasai materi pelajaran guna mencapai prestasi yang maksimal.

Berdasarkan fenomena di atas maka peneliti merasa tertarik untuk melakukan penelitian dengan judul Upaya Meningkatkan Hasil Belajar Ekonomi Melalui Model pembelajaran Kooperatif Tipe Jigsaw Pada Peserta Didik Kelas XI-8 SMAN-4 Palangka Raya. Tujuan dari penelitian ini adalah sebagai berikut:

1. Untuk mendeskripsikan aktivitas belajar peserta didik kelas XI-8 SMAN-4

Palangka Raya dalam pembelajaran Ekonomi dengan menggunakan Model Pembelajaran Kooperatif Tipe Jigsaw.

2. Untuk meningkatkan hasil belajar Ekonomi peserta didik kelas XI-8 SMAN-4 Palangka Raya setelah menggunakan Model pembelajaran Kooperatif Tipe Jigsaw.

\section{METODE PENELITIAN}

Penelitian yang digunakan adalah Penelitian Tindakan Kelas (PTK) yang dilakukan oleh peneliti secara langsung.

Menurut Kunandar (2010:46) penelitian tindakan kelas adalah suatu penelitian yang berbasis kepada kelas. Penelitian dapat dilakukan secara mandiri, tetapi alangkah baiknya dilaksanakan secara kolaboratif, baik dengan teman sejawat, kepala sekolah, pengawas, widyaswara, dosen, dan pihak yang relevan degan PTK.

Dari beberapa pendapat di atas, dapat disimpulkan bahwa penelitian tindakan kelas adalah penelitian yang dilakukan guru secara sistematis dalam kegiatan belajar berupa sebuah tindakan dalam sebuah kelas secara bersamaan melalui refleksi diri untuk meningkatkan hasil belajar peserta didik. Arikunto Suharsimi ( 2002 ). Prinsip Penelitian Tindakan Kelas:

a. Kegiatan nyata dalam situasi rutin

b. Adanya kesadaran diri untuk memperbaikin kinerja

c. Swot sebagai dasar berpijak

d. Upaya empiris dan sistemik

e. Ikuti prinsip SMART dalam perencanaan

Dalam penelitian ini PTK yang digunakan adalah berkolaborasi dengan guru dimana secara keseluruhan Penelitian ini mencakup kegiatankegiatan seperti:

1. Perencanaan, mencakup membuat rencana pembelajaran, membuat lembar observasi, 
2. Melakukan tindakan, melaksanakan semua perencanaan yang telah disusun,

3. Pengamatan, melakukan pengamatan dengan mengisi lembar observasi,

4. Refleksi, kegiatan mengingat dan merenungkan kembali suatu tindakan yang berdasarkan catatan pengamatan.

\section{HASIL DAN PEMBAHASAN}

Hasil penelitian memuat pengolahan data tentang (1) nilai hasil belajar, (2) hasil pengamatan aktivitas peserta didik dalam kegiatan belajar mengajar.

1. Hasil pengamatan terhadap aktivitas peserta didik dalam Kegiatan Belajar Mengajar (KBM)

Hasil penelitian dapat di uraikan bahwa skor aktivitas belajar peserta didik pada siklus I oleh pengamat I $(41,14)$ dan pengamat II $(43,22)$, secara individual terdapat 16 peserta didik yang mendapat skor $\geq 45$, dan 21 peserta didik yang mendapat skor dibawah 45, sehingga aktivitas peserta didik pada siklus I belum bisa dikatakan baik. Skor aktivitas belajar peserata didik pada siklus II oleh pengamat I $(45,97)$ dan pengamat II $(47,14)$ secara individual terdapat 33 peserta didik yang mendapat skor $\geq 45$, dan 4 peserta didik yang mendapat skor dibawah 45, sehingga aktivitas peserta didik pada siklus II sudah dikatakan baik atau telah mencapai indikator keberhasilan.

2. Nilai Hasil Belajar Peserta Didik Meningkatnya nilai hasil belajar peserta didik kelas XI8 SMAN 4 Palangkaraya pada mata pelajaran Ekonomi tentang materi Pasar Modal, dikarenakan meningkatnya pemahaman materi pada peserta didik. Hal ini dikarenakan adanya model pembelajaran Kooperatif Tipe Jigsaw yang digunakan untuk mempermudah pemahaman peserta didik pada saat pembelajaran berlangsung, yaitu dengan menggunakan model pembelajaran Kooperatif Tipe Jigsaw.

Tabel 1

Peningkatan Hasil Belajar Peserta Didik

\begin{tabular}{|c|c|}
\hline Jenis Test & $\begin{array}{c}\text { Presentase Ketuntasan } \\
\text { Hasil Belajar }\end{array}$ \\
\hline Pre Test & $2,43 \%$ \\
\hline Post Test I & $4,86 \%$ \\
\hline Post Test II & $6,49 \%$ \\
\hline
\end{tabular}

Maka dapat diketahui bahwa hasil belajar peserta didik dari pre-test sampai post test siklus II telah mengalami peningkatan, pada pre test persentase ketuntasan klasikalnya hanya mencapai $32,43 \%$ dengan kategori belum tercapai, siklus I persentase ketuntasan klasikalnya mencapai $64,86 \%$ dengan kategori belum tercapai, siklus II ketuntasan klasikalnya lebih meningkat hingga $86,49 \%$ dengan kategori tercapai. Berdasarkan hasil 
penelitian yang diperoleh maka dapat diketahui bahwa dengan menggunakan model pembelajaran Jigsaw dalam pembelajaran Ekonomi materi Pasar Modal dapat meningkatkan aktivitas dan hasil belajar peserta didik.

\section{KESIMPULAN}

Berdasarkan hasil penelitian yang telah dibahas maka dapat disimpulkan beberapa hal yaitu :

1. Aktifitas belajar peserta didik aktif pada saat proses pembelajaran Ekonomi dengan menggunakan model pembelajaran Kooperatif Tipe Jigsaw pada peserta didik kelas XI-8 SMAN 4 Palangkaraya.

2. Ada peningkatan hasil belajar Ekonomi setelah menggunakan model pembelajaran Kooperatif Tipe Jigsaw pada peserta didik kelas XI-8 SMAN 4 Palangkaraya.

Hal ini telihat dari data hasil belajar peserta didik, pada siklus I ratarata hasil belajar peserta didik yaitu 70,14 dan ketuntasan secara klasikalnya yaitu $64,86 \%$ dan pada siklus II meningkat menjadi 83,24 dan ketuntasan klasikalnya yaitu $86,49 \%$. Adapun standar ketuntasan minimum yang ditentukan sekolah untuk pelajaran Ekonomi yaitu 75 .
Ibrahim, dkk. (2003). Perencanaan Pembelajaran. Bandung: PT. Remaja Rosdakarya

Kunandar. (2012). Langkah Mudah Penelitian Tindakan Kelas Sebagai Pengembangan Profesi Guru. Jakarta: PT Raja Grafindo Perdasa.

Nurhadi. ( 2004 ). Perencanaan Pembelajaran. Bandung: PT. Remaja Rosdakarya.

Slameto. ( 2003 ). Strategi Pembelajaran. Bandung: Pustaka Setia.

Suharsimi, Arikunto, dkk. (2002). Prinsip Penelitian Tindakan Kelas, Jakarta: PT Bumi Aksara

Undang-Undang RI, (2003), Tentang Sistem Pendidikan Nasional. Bandung: Citra Umbara.

Wena, Made. (2010). Strategi Pembelajaran Inovatif Kontemporer suatu Tinjauan Konseptual Operasional. Jakarta: Bumi Aksara.

\section{DAFTAR PUSTAKA}

